The effect produced without and with the diaphragm will be seen in Fig. 3 .

Figs. 4 and 5 illustrate shakes, and show clearly the importance of equality of touch; they show, too, how precisely the apparatus reproduces any irregularity.

Many questions have to be considered with regard to quick playing, but one of the most striking features is that the more quickly the notes are played, the more the force of the movement diminishes, until finally a certain stage is reached, when the amplitude ceases to vary.

Let us now consider the advantages of the instrument ; they are threefold.

(I) Dealing with its advantage from the psychological point of view, it is found that the voluntary movements of the pianist can be observed without putting him to any restraint or embarrassment, for the small tube does not affect the resistance of the notes, nor is the exterior of the piano altered.

(2) For teaching purposes the device has been of great use. The record on the roll of paper shows the faults so precisely, that although they are scarcely perceptible to the ear, there is no denying their existence.

(3) We are well aware that written music cannot show every slight change in the time the composer might desire. By applying the graphical method, this difficulty is eliminated, and the time will be reproduced with the smallest details.

\section{THE NEW METEOROLOGICAL STATION ON MOUNT WELLINGTON.}

AIEW of the new meteorological observatory on A Mount Wellington, Tasmania, is shown in the accompanying illustration. As we announced in a previous issue (July 25), the observatory was begun in
Weather Bureau, Brisbane, has organised the stations. Very valuable results, bearing upon the distribution of pressure, temperature and humidity attaching to anticyclonic and cyclonic systems through vertical sections of the atmosphere in the northern and southern hemispheres respectively, will probably be forthcoming when the Mount Wellington and Hobart results appear and are discussed side by side with those obtained at Ben Nevis and Fort William. Except for a few degrees of latitude, Mount Wellington and Hobart are geographically and physiographically almost the very counterparts in the southern hemisphere of Ben Nevis and Fort William in the northern. Mr. Wragge has entirely reorganised the Tasmanian Government Meteorological Service on federal principles in direct connection with the Queensland Weather Service, and he was enabled to perform this work through the courtesy of the Queensland Government, who allowed him as their officer to render federal aid in the cause of science to the sister colony. Mr. H. C. Kingsmill has charge of the Tasmanian section.

\section{DR. E VON REBEUR-PASCHIVITZ.}

F VON REBEUR-PASCHWITZ was born in I86I, F. and died, after an illness of ten years, on the first of the present month. In many ways he always seemed to me to resemble our incarnation of the ideal man of science. He had Darwin's lovable nature, as well as his modesty and utter carelessness of his own fame. But the likeness was closest in the unceasing energy with which he laboured, in spite of the constant suffering that would have made many stronger men feel their life's work was done.

For sometimevon Rebeur-Paschwitz was a Privat-docent in Astronomy at the University of Halle. His first notable

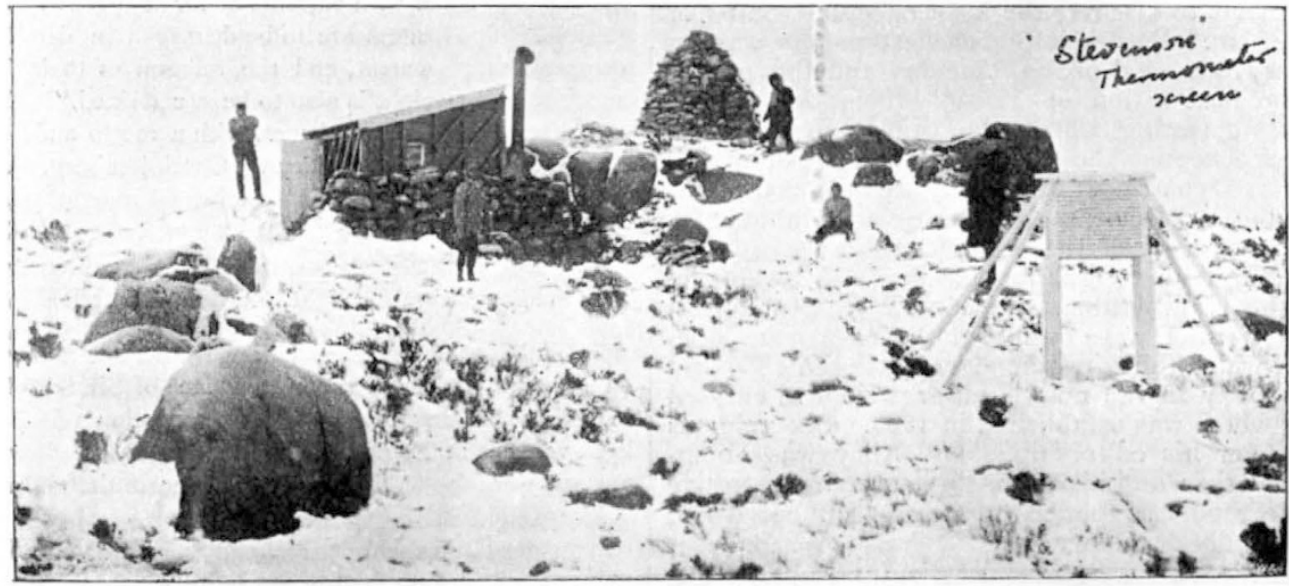

The Observatory, Mount Wellington (4I66 feet above sea-level).

May last, and it will be to the southern hemisphere what the Ben Nevis and other high-level observatories are to the northern. Mount Wellington is about four miles distant from Hobart, and rises almost directly from the level of the sea. The station is supplied with a "Fortin" mountain barometer, "Richard" barograph and thermograph, dry-wet, and maximum and minimum, thermometers, as well as a " 5 -inch" gauge with extra deep rim for retaining snow. Similar instruments are in use at the Springs $(2495 \mathrm{ft}$.) and at Hobart, I 60 feet above sea-level. Mr. Clement L. Wragge, Superintendent of the Chief achievement was, I believe, the modification of Zöllner's horizontal pendulum, the two springs by which it was supported being replaced by agate cups resting on fine steel points. The earlier investigations with this instrument were intended to be of an astronomical character, but its wonderful sensitiveness to the pulsations of distant earthquakes soon became apparent, and he was gradually led to give more time to their study, until he became the chief authority on this fascinating branch of seismology. On two occasions he contributed articles to Niturli on this subject (vol. xl. pp. $294-295$; vol. li. pp

NO. I 355 , VOL.. 52 ] 
208-2I I), and, at the request of the Earth Tremors Committee of the British Association, he wrote an admirable summary of his results up to the middle of 1893 . As this is readily accessible, it is unnecessary to enlarge upon his achievements here. I will merely add that since that date he has written several papers on earthquake-pulsations in Petermann's Mittheilungen and the Astronomische Nachrichten. His last memoir, and one of the most valuable, has just been published in Gerland's Beiträge zur Geophysik.

For several months before his death, von RebeurPaschwitz was occupied with a scheme for the organised study of earthquake-pulsations all over the globe. The suitability of his horizontal pendulum for this purpose had received ample proof, and nothing but the want of health seemed likely to prevent the fulfilment of his plans. These, no doubt, will be carried out by other, if less skilful, hands; but to him will belong a great part of the credit for any results that may be attained. Dying at thirty-four, he had done work which most men of twice the age might regard with satisfaction as the fruits of a well-spent life. CHARLES DAVISON.

\section{CHARLES $V$. RILEY.}

CHARLES V. RILEY, M.A., Ph.D., whose death on the I $4^{\text {th }}$ ult., in consequence of injuries received in a fall from a bicycle in the streets of Washington, was announced in these columns on October 3 , was an Englishman, born at Walton-on-Thames in 1843 . He emigrated to the United States at the age of seventeen, and settled, as we learn from the Garden and Forest, on a farm in Illinois. Like so many other Americans, who have since made a reputation in science, he served as a soldier in the civil war. Subsequently, after some experience as a journalist, he was appointed State Entomologist of Missouri, a position he occupied nearly ten years. I) uring this period he did excellent work in the investigation of the life-histories of insects injurious to plants, and experiments to discover the most effectual means of destroying them. But one of his earliest papers was on a new genus (Pronubia) of the Tineide, and the part it plays in the fertilisation of Yucca. ${ }^{1}$ This was an important and interesting contribution to biological science. In 1878 he accepted the post of Entomologist to the United States I)epartment of Agriculture at Washington, where, in the words of the authority cited above, he practically supervised all the entomological work of the Government until his resignation last year. The valuable results of the investigations and experiments conducted by him and his staff, were in part published in occasional bulletins, of which thirty-two appeared between 1883 and I 894, and partly in the now familiar periodical entitled Insect Life, which was established in 1888 . Six volumes appeared under his editorship. Dr. Riley was an indefatigable worker, and his organising and administrative abilities were well exemplified in the department which he so successfully developed.

W. B. H.

\section{NOTES}

IT is stated that in order to enable the Berlin Academy of Sciences to issue a complete edition of Kant's works, the Government of Russia has consented to place at its disposal for a time the philosopher's manuscripts belonging to the University of Dorpat.

AcCORDris to the British Mexical Journal, the New York Pasteur Institute has purchased thirty-five acres of land near Tuxedo Park, on which an experiment station is to be established. The station will be stocked with cows, horses, sheep, and goats, which will be used for the production of diphtheria

\footnotetext{
1 Transactions of the Acadeny of Science of St. Louis iii. (1873) p. 55
}

NO. I 355 , VOL. 52 ] and cancer antitoxins. The situation is healthy, and in the grounds there will be a house in which some of the patients of the Institute will be treated. A new station, to be known as the Pasteur Station, will be established on the Eric Railroad, close at hand.

WE regret to notice the following announcement in Sience:"Prof. Ernst Ritter, whose appointment as assistant professor of mathematics in Cornell University was recently announced, died on September 23, of typhoid fever, on his arrival in America from Germany. Ernst Ritter was born at Waltershausen, Germany, on January 9, I867. He spent twelve years at the Gymnasium at Gotha, and afterwards studied mathematics and natural science under Thomas, at Jena, and under Klein and Schwartz, at Göttingen. In I 890 he passed the Government teacher's examination with the highest distinction, after two years of pedagogical work at Cassel, and at the Wöhlerschule in Frankfurt. He took the degree of Ph.D., summa cum laude, at Göttingen in I892. In 1893 he was appointed assistant to Prof. Klein, and began to devote his entire time to mathematics, contributing regularly to mathematical periodicals. Last year he lectured on geometry and the theory of automorphic functions, in which he was an authority. He was appointed to his Cornell professorship last June."

WE learn from the Joumal of the Franklin Institute that the German Hygienic Association offers a prize of I 200 dols. for a research essay on the efficiency of electric heaters. The programme is as follows: "The heat given out in heating installations by heaters in their various forms and modes of use is to be ascertained. The investigations are to be described in detail in respect to the arrangement of the heaters, the nature of the heating agents, and the observations made; and they are to be illustrated by drawings. The heating values obtained are to be stated in units of heat given off per hour per unit of surface. In the case of heat given out to air, the investigations must be conducted with currents of air at speeds as different as possible. The heaters are to be described in detail as regards form and measurement, and the relation of their heating efficiency to their weight is also to be ascertained." Essays are to be written in German, and sent, with a motto and sealed envelope, to Prot. Konrad Hartmann, Charlottenburg, Fasannstrasse 18, before July I, I896. The essay will remain the property of the successful competitor, but he is required to publish it within six months, and to give the prize offerers gratuitously 300 copies. The offerers reserve the right to divide or withhold the prize.

THE display of horseless carriages, held at Tunbridge Wells on Tuesday, under the superintendence of Sir David Salomons, will do something towards the introduction of self-propelling light vehicles in England. Two carriages, fitted with Daimler motors, were shown in operation. One of these, that belonging to Sir David Salomons, weighs $\mathrm{I}_{3}$ cwt., and will run nearly two hundred miles without recharging. The motor has a horsepower of $3 \frac{3}{4}$, and a speed of fifteen miles an hour can be attained on a level road, while on a gradient of one in ten a speed of four miles an hour is reached. A mechanical tricycle, worked by a petroleum motor with electric spark ignition, was shown by MM. de Dion and Bouton, of Paris. The tricycle can rua at a rate of fourteen miles an hour, and only needs a fresh supply of benzine after about six hours' work. The exhibition proved the capabilities of auto-mobile carriages to a large number of spectators, and it will probably do something to bring about a change in the present vexations Highways and Locomotives Act, which at present limits the rate of speed of self-propelled carriages to two miles an hour, and makes it necessary for a man carrying a red flag to precede the carriage as a warning of approaching danger! 